\title{
Geochemical behavior of REE associated with Laterization process in Daklak Province, Southern Viet Nam
}

- K. Okamura

- K. Watanabe

- K. Yonezu

- Dang Thuong Huyen

- Do Cong Du

- Tran Anh Tu

Kyushu University, Japan - okamura-koki@kyushu-u.ac.jp

(Manuscript Received on August 011 $1^{\text {th }}$, 2014; Manuscript Revised November 11 $1^{\text {th }}$, 2014)

\section{ABSTRACT:}

The importance of REE for modern industries is proved by the high demand. The abundance of $R E E$ is richer than that of noble metals like gold or silver. However, supply sources are concentrated in China. The share of the product of REE was highest in 2009 (over 90\%) and that is used as a national strategy.Mining industry in Vietnam is mainly developed in northern part. Deposits of principle metals are located around Hanoi, and REE deposits (Dong Pao) is also explored in Lai Chau Province. On the other hand, few bauxite mine is in southern Vietnam and the REE exploration is not conducted enough. Therefore, the study about REE in southern Vietnam is significant. Samples are from mainly basalt and granite. REE pattern, which is normalized by the abundance of chondrite, of basaltic rocks and laterites shows that is decreases monotony. That amount of REE is low (50-180ppm). REE pattern of magnetite rocks and laterites has no Eu and Ce anomaly. On the other hand, illuminate rocks and laterites have strong negative Eu anomaly. Clay minerals were observed by XRD analysis using hydraulic elutriation. The result of REE pattern and sequential extraction, it is indicated that the form of HREE is changed and adsorbed to clay and LREE is leached out. In tailing in Stop 16, it is observed that the concentration of HREE (about 3 times to 5 times than that of before washing). Eu anomaly is affected by reductive environment of the cooling of magma, and it is considered that $\mathrm{Ce}$ anomaly is occurred by the change of Ce form $\left(\mathrm{Ce}^{3+}\right.$ to $\left.\mathrm{Ce}^{4+}\right) . \mathrm{CeO}_{2}$ is insoluble to water in the soil. From the XRD analysis, the cause of HREE concentration in water treatment is considered by the clay mineral.

Keywords: Vietnam, Geology, REE, Weathering, Lateri.

\section{INTRODUCTION}

Rare earth elements are essential for various types of modern industries. For example, the abundance of REE is much than the noble metals; $\mathrm{Au}, \mathrm{Ag}$ or Pt. However, it is difficult to refine REE because of these electron configurations. In addition, beneficial deposits of REE are uneven. Actually, the production of China accounts for over $90 \%$ of that of the world. Therefore, it is important to study the concentration mechanism of REE in different types of deposits as well as to determine REE and associated elements.

There are some deposit types of REE. In Chine, the deposit of ion adsorption type in which the REE are adsorbed to clay with ion exchange is developed mainly. On the other hand, the other deposit type which is derived from laterites is existed. By the influence of 
rainwater, only a few elements remain in the laterites formed from granites or basalts: Fe and Al.In contrast, REE, $\mathrm{SiO}_{2}$ and some minerals are easily mobilized. Therefore, the contents of $\mathrm{Al}$ in well-weathered laterites tends to high and that of REE is low. However, like a ion adsorption type in China, REE are sometimes concentrated in clay minerals. Vietnam exhibits a typical tropical climate that is ideal for laterite formation. In Vietnam, the main host rocks of laterites are granite and basalt and bauxite is one of its main mineral products. It is widely distributed from central to southern Vietnam, and is recently being developed by Chinese companies. Tan Rai mine started the operation at 2012 by Chalieco Co, China. The amount of production is about $650 \mathrm{kt}$. The exploitation of Nyan Co mining area is finished recently. The amount of bauxite is supposed to be produced about 600kt a year. In addition, Kon Ha Nung is evaluated and it will be considered based on the result of Tan Rai and Nyan Co mine. Vietnam also produces some metals: titanium (399.9kt), zinc (36kt) and copper (8.3kt) (World Metal Statistics Yearbook 2011). Most of these metal mines are located in the northern part of Vietnam.

There is a significant difference between the northern and southern portion of Vietnam in terms of geologic features. Paleozoic and Proterozoic systems dominate in the northern part. On the other hand, Mesozoic rocks, as well as Neogene-Quaternary basaltic and felsic rocks are distributed in the southern portion (JOGMEC 2004). In the study area, heavy laterization developed because of the high amount of rainfall. Typical laterite in the area is brown due to the high $\mathrm{Fe}_{2} \mathrm{O}_{3}$ content. Samples are collected from outcrops and from the bauxite mine. The objective of this study is to reveal the relationship between the weathering of laterites and the resultant REE concentration based on experimental data. In addition, the study can aim to investigate the presence of REE in the bauxite ore and in the mine tailings. Several analysis were conducted to compare the type of host rocks and the extent of weathering. Samples taken from the bauxite deposit were also analyzed to know the REE amount in the tailing.

This research evaluates the potential of laterites from granites and basalts as well as the bauxite deposits in terms of REE potential. That will also provide the information about the amount of REE and the concentration of that. The results from this study shows the utility that may affect the mineral resources development of Vietnam.

\section{GEOLOGICAL SETTINGS}

Vietnam is divided into the South China Plate and the Indochina plate (Fig.1). The plate boundary is the Red River fault which strikes NW-SE over $1000 \mathrm{~km}$ (Tapponnier et al., 1990). The Red River fault zone is configured from narrow metamorphic cores of the fault zone (the Ailao Shan-Red River shear zone) and the active Red River fault system (Leloup et al., 1994). The Indochina plate was extruded as an effect of the collision of India with Asia.Rock units from PreCambrian to Quaternary are distributed throughout Vietnam.

There are Pre-Cambrian formations along the axis of the Red River valley. Lower Proterozoic rocks are found at the Red River fault zone and in the middle portion of Vietnam. The strata thickness is estimated to be $2500 \mathrm{~m}-3000 \mathrm{~m}$. The composition of the lowest part is mainly amphibolite-biotite gneiss, hornblend-biotite plagiomigmatite and intercalations of amphibolites (Tri et al., 1977). Upper Proterozoic metamorphic rocks are distributed in the southern part, with a thickness of $1000-1200 \mathrm{~m}$. The main composition is amphibolite with garnet and cummingtonite, with intercalations of marble and plagioclase-diopside schists in the lower part. In the upper portion, mica schist, gneiss, quartzite, amphibolite and marble are formed (Hai 1986).

Paleozoic formations are widespread in the northern part of Vietnam, but there are a few zones in the southern part (Fig.2). Limestone, mudstone and sandstone comprise the middle Cambrian-lower Ordovician formations, which is $1300-2000 \mathrm{~m}$ thick. Middle and Upper Ordovician strata (400-1000m thick) are composed of coarse grained clastic rocks with traces of brachiopods fossils (e.g. Vietnamia douvillei (MANS) and Lonchodomas yohi SUN) and other taxa. The strata from 2000-3500m thick are Upper Ordovician-Upper Silurian in age. These strata have fossil taxa remains and are largely distributed in the North-east (Ngan et al., 1986).

The Mesozoic formations consist of sedimentary rock: Triassic and Jurassic marine sediments, and

\section{Trang 70}


Cretaceous terrigenous and volcanic rocks. These rocks are distributed in Mesozoic grabens. The Triassic strata mainly consist of terrigenous deposits, volcanic rocks, and limestone that contains rich fossil assemblages of pelecypods (Khuc \& Thu 1986). The Cretaceous formation mainly consist of sandstone, siltstone, shale and conglomerates (Thu \& Tien 1986).

The Tertiary rock formations, which mainly consist of Neogene strata belong to three types of strata: lacustrine with the intercalation of volcanic rocks; lagoonal or deltaic: and marine. The lacustrine deposits are rhythmically interbedded with conglomerates, coarse sandstone and coal-bearing units. Basalts are often distributed with these deposits. The areas in and around Hanoi \& Mekong are surrounded by lagoonal or deltaic formations. Marine formations are only found on the continental shelf of Vietnam (Dzanh 1986).

Quaternary strata is mainly distributed throughout Vietnam. Deltaic sediments are found in the Hanoi \& Mekong basins and coastal plains. In the highland, basalts are widespread around the central part of Vietnam (Tran 1995).

Intrusive rocks in Vietnam are divided into five stages: Archean, Early Proterozoic, Early-Middle Paleozoic, Late Paleozoic-Early Mesozoic and Late Mesozoic-Cenozoic. Archean strata are mainly found in central part of Vietnam with composition varying from ultramafic to granitic. Proterozoic rocks typically intrude metamorphic rock structurally. The bodies are mainly plagiogranite and migmatite. The Early-Middle Paleozoic intrusions are widespread over Vietnam and have compositions varying from ultramafic to granitic. The Late Paleozoic-Early Mesozoic intrusive rocks mainly consist of granodiorite and granite. The Late Mesozoic-Cenozoic is characterized by high-alumina granitoid, alkaline granite and alkaline syenite (Tran 1995).

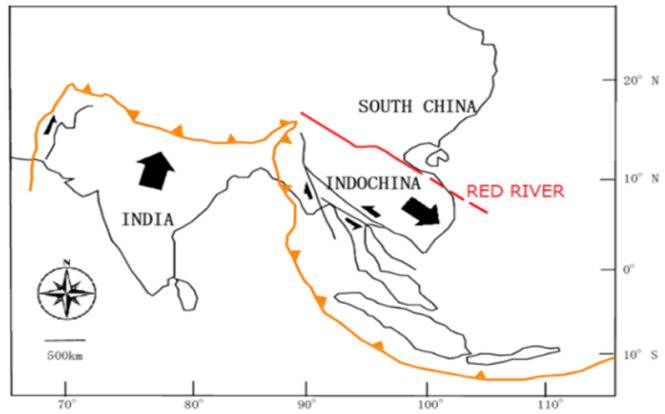

Figure 1. Schematic techtonic map of Cenozoic fault zone (After Shaker et al., 1990)

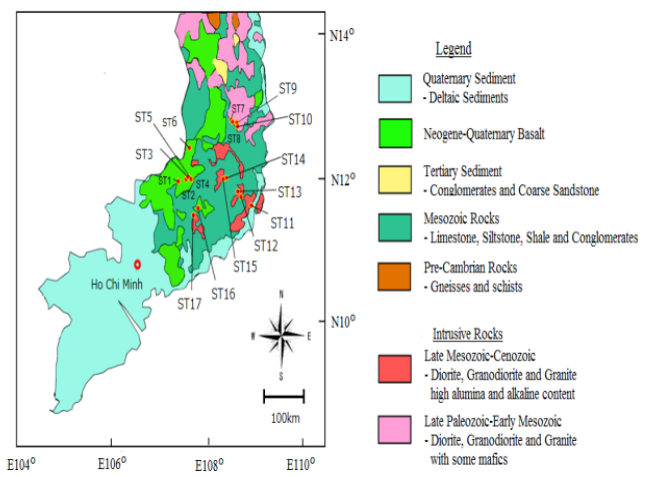

Figure 2. Geological Map of Southern Vietnam (Tran and Nguyen, 1986)

\section{SAMPLING AND ANALYTICAL METHODS}

Granitoids and Basaltic samples were taken from each location (ST17 from ST1, Fig.2). Whole host rocks can be classified in detail by the chemical composition, and granitoids can be also classified into Magnetite series (magnetic susceptibility $>0.3$ ) and ilmenite series (magnetic susceptibility < 0.3 ). The chemical composition is analyzed by X-ray Fluorescence Analysis (XRF), and the identification of minerals is conducted by X-ray diffraction (XRD). The method of sequential extraction and Inductively Coupled Plasma Mass Spectrometry (ICP-MS) are used for knowing the relationship between the amount of REE in samples and laterization process.

Sequential extraction (e.g., Miller et al., 1986) is one of the ways to trace REE.The samples are milled and the amount used for analysis is $0.5 \mathrm{~g}$. The samples are dissolved by reagents and the resulting solution is separated from the sample (Table.1). 


\begin{tabular}{|c|c|c|}
\hline \multicolumn{3}{|c|}{ Table 1. Sequential Extraction } \\
\hline Step & Regent & Form \\
\hline 1 & $0.5 \mathrm{M} \mathrm{Ca}\left(\mathrm{NO}_{3}\right)_{2}$ & Ion Exchangeable \\
\hline 2 & $0.44 \mathrm{M} \mathrm{CH}_{3} \mathrm{COOH}$ & Asid Soluble \\
\hline 3 & $\begin{array}{l}0.01 \mathrm{M} \mathrm{NH}_{2} \mathrm{OH}-\mathrm{HCl} \\
+0.1 \mathrm{M} \mathrm{HNO}_{3}\end{array}$ & Mn-Oxide-Occluded \\
\hline 4 & $0.1 \mathrm{M} \mathrm{K}_{4} \mathrm{P}_{2} \mathrm{O}_{7}$ & Organically bound \\
\hline 5 & $\begin{array}{l}0.175 \mathrm{M}\left(\mathrm{NH}_{4}\right)_{2} \mathrm{C}_{2} \mathrm{O}_{4} \\
+0.1 \mathrm{M} \mathrm{H}_{2} \mathrm{C}_{2} \mathrm{O}_{4}\end{array}$ & $\begin{array}{c}\text { Amorphous Fe-Oxide- } \\
\text { Occluded }\end{array}$ \\
\hline 6 & $0.5 \mathrm{M} \mathrm{H}_{2} \mathrm{C}_{2} \mathrm{O}_{4}$ & $\begin{array}{c}\text { Crystalline Fe-Oxide- } \\
\text { Occluded }\end{array}$ \\
\hline
\end{tabular}

\section{RESULTS}

Features of the granite is represented in each REE patterns. REE pattern is normalized by the REE contents in chondrite, which is considered to have original composition of earth, and that is used for knowing the increase and decrease of REE. REE pattern of ilmenite-series granitoids (I-Fresh or I-Weathered) has Eu anomaly, but that of magnetite series granitoids (M-Fresh or M-Weathered) has no anomaly (Fig.4 and Fig.5). These results was revealed by measurement using ICP-MS. The samples of magnetite series, there is a tendency which is rich in LREE than HREE in host rock and weathered rock. Therefore, the value that has been standardized to decrease monotonically with increasing atomic number. On the other hand, the sample of ilmenite series, has a negative Eu anomalies described above, and Ce positive anomaly is observed in some samples. The major feature of southern Vietnam, normalized value are flat or increasing with increasing atomic number. In fact, the trend is shown in the table. However, samples with this feature is only weathered samples. Granitoids of ilmenite series (host rock) have a REE pattern similar to the granitic rocks of the magnetite system. Therefore, the granitic rocks of ilmenite series, there is a possibility that the selective leaching of LREE, or the concentrated of HREE is happening in the process of weathering.

REE concentration in the sample of magnetite series is $140 \sim 650 \mathrm{ppm}$. On the other hand, samples of ilmenite series, the amount of total REE is $80 \sim 630 \mathrm{ppm}$. Changes in concentr- ation depending on the depth is not so large, but it can be seen that the concentration is high in some points (Table.2).

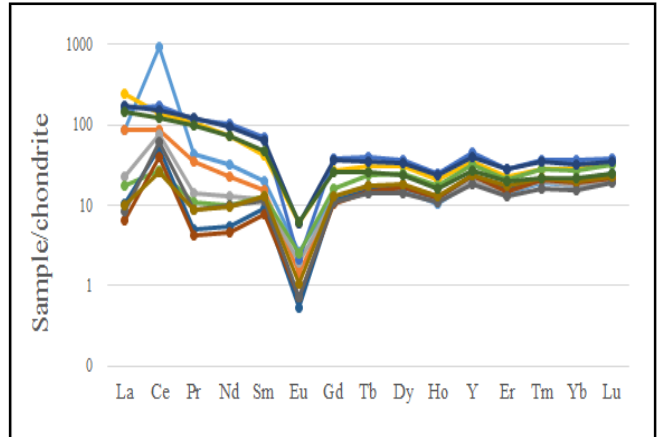

Figure 3. REE pattern of ilmenite series.

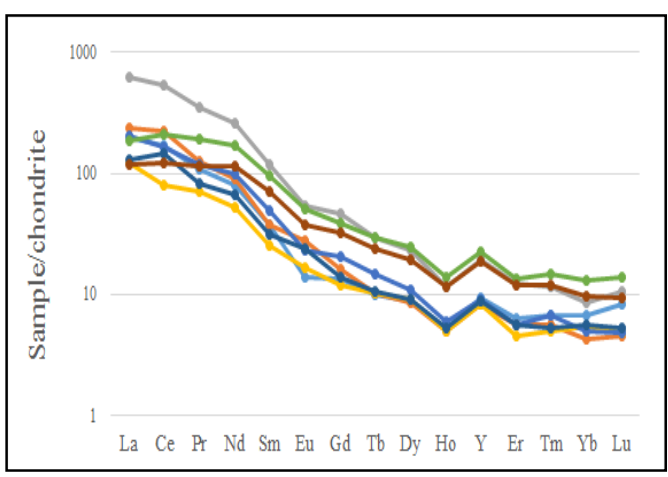

Figure 4. REE pattern of magnetite series

But the concentration of Ce occupying the REE is very high in some samples. Therefore it is not possible to easily associate the enrichment height and density. $\mathrm{La}$ / $\mathrm{Yb}$ shows the percentage of HREE to LREE in the sample, a sample of ilmenite series is shown to have HREE ratio higher than the sample of magnetite series. Trend of a sample of basalt is similar to the granitic rocks of the magnetite series. However, after the washing process, REE pattern of weathered rock appears to be relatively rich in HREE. However, the concentration of Sc and REE was low (REE: 10 70ppm and Sc: $10 \sim 21 \mathrm{ppm}$ ).

Sequential extraction can know the form of the REE in soil (Table.1). Ratio of each element is extracted as acid soluble was high in that REE concentration increases in ST9 (Fig.6). Extraction ratio of REE in Step7 are highest in ST14 and ST15, but the extraction ratio are about $80 \%$ in these samples when the $\mathrm{Ce}$ is excluded. However, it is impossible to be extracted all REE in soil.In this experiment, it can be extracted from about 40 to $60 \%$ of total REE in samples.Actuary, the average of extraction rate of weathering rock sample was $56 \%$. From basalt samples, which was obtained in

\section{Trang 72}


ST16, it was not possible to extract most of REE. Extraction of REE in second step, indicating that there is a possibility that REE is adsorbed on clay minerals. In fact, by the XRD measurement, clay minerals such as kaolinite and halloysite, were identified from ST14 and ST15 samples. It is also revealed that clay mineral are present in basaltic samples. The size of these tailing samples are slightly different, so Table. 2 also shows the difference in concentration of REE by the particle size.

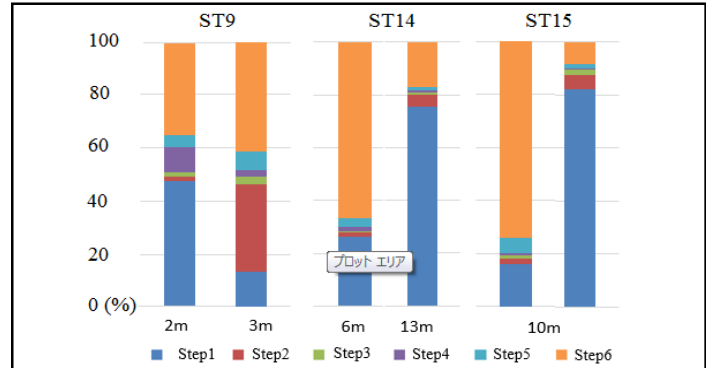

Figure 5. Result of Sequential Extraction (in ST15, right shows total ratio of REE and left shows REE excluded the effect of $\mathrm{Ce}$ )

Table 2. Concentration of REE, and the ratio between $\mathrm{La}$ and $\mathrm{Yb}$

\begin{tabular}{|c|c|c|c|c|c|c|}
\hline Sample & Type & $\operatorname{Depth}(\mathrm{m})$ & $\Sigma$ LREE & $\Sigma$ HREE & $\Sigma$ REE & $\mathrm{La} / \mathrm{Yb}$ \\
\hline \multicolumn{7}{|c|}{ ST9 } \\
\hline A & M-Weathered & 1 & 204.8 & 22.8 & 227.6 & 43.9 \\
\hline $\mathrm{B}$ & M-Weathered & 2 & 251.2 & 20.9 & 272.0 & 81.2 \\
\hline $\mathrm{C}$ & M-Weathered & 3 & 648.4 & 51.0 & 699.4 & 105.2 \\
\hline $\mathrm{D}$ & M-Weathered & 4 & 112.6 & 20.0 & 132.6 & 33.0 \\
\hline$E$ & M-Fresh & - & 213.9 & 24.0 & 238.0 & 59.7 \\
\hline \multicolumn{7}{|c|}{ ST14 } \\
\hline $\mathrm{A}$ & I-Weathered & 6 & 598.5 & 44.5 & 643.1 & 7.4 \\
\hline $\mathrm{B}$ & I-Weathered & 9 & 88.7 & 48.9 & 137.6 & 6.4 \\
\hline $\mathrm{C}$ & I-Weathered & 11 & 61.9 & 45.1 & 107.0 & 1.9 \\
\hline $\mathrm{D}$ & I-Weathered & 13 & 191.4 & 78.5 & 269.9 & 12.3 \\
\hline $\mathrm{E}$ & I-Fresh & - & 212.3 & 101.5 & 313.7 & 6.6 \\
\hline \multicolumn{7}{|c|}{ ST15 } \\
\hline $\mathrm{A}$ & I-Weathered & 1 & 28.7 & 71.5 & 100.3 & 1.0 \\
\hline $\mathrm{B}$ & I-Weathered & 3 & 39.0 & 51.8 & 90.8 & 0.7 \\
\hline $\mathrm{C}$ & I-Weathered & 6 & 29.5 & 50.4 & 79.9 & 0.5 \\
\hline $\mathrm{D}$ & I-Weathered & 10 & 46.8 & 41.1 & 87.9 & 0.8 \\
\hline E & I-Weathered & 15 & 25.2 & 53.0 & 78.3 & 0.7 \\
\hline $\mathrm{F}$ & I-Fresh & - & 197.3 & 91.6 & 289.0 & 8.2 \\
\hline $\mathrm{G}$ & I-Fresh & - & 160.3 & 63.7 & 224.0 & 10.0 \\
\hline \multicolumn{7}{|c|}{ ST16 } \\
\hline $\mathrm{A}$ & Weathered & 1 & 33.9 & 12.2 & 46.0 & 11.3 \\
\hline $\mathrm{B}$ & Weathered & 2 & 21.8 & 7.8 & 29.6 & 11.1 \\
\hline $\mathrm{C}$ & Weathered & 3 & 26.2 & 9.5 & 35.7 & 9.1 \\
\hline $\mathrm{D}$ & Weathered & 4 & 26.4 & 6.4 & 32.8 & 15.5 \\
\hline $\mathrm{E}$ & Weathered & 6 & 11.1 & 3.2 & 14.3 & 8.9 \\
\hline $\mathrm{F}$ & Tailing & - & 32.1 & 17.4 & 49.5 & 6.9 \\
\hline $\mathrm{G}$ & Tailing & - & 38.0 & 23.1 & 61.1 & 5.2 \\
\hline $\mathrm{H}$ & Weathered & - & 30.7 & 5.3 & 36.0 & 30.4 \\
\hline $\mathrm{I}$ & Weathered & - & 17.4 & 4.5 & 22.0 & 15.1 \\
\hline
\end{tabular}

\section{CONCLUSION}

REE that is included in the granitic rocks of the magnetite system is about $140 \sim 650 \mathrm{ppm}$. Host rocks is rich in LREE, and the amount of REE is highest at the point of $3 \mathrm{~m}$ depth. In addition, minerals including REE as xenotime and clay are not identified. Therefore, it is considered that there is a mechanism of enrichment of something, like the volume reduction of the rock by weathering. Ce anomaly is seen in the case of weathered-granitic rocks of ilmenite series. $\mathrm{Ce}$ is extracted with step7 primarily. In step7, Ce4+ (unsoluble)becomes $\mathrm{Ce} 3+$ (soluble) by reduction of oxalic acid used in step7. Therefore, it is considered that $\mathrm{Ce}$ is present as an oxide of tetravalent in the soil. By the result of sequential extraction, REE except Eu and $\mathrm{Ce}$, are extracted with Step2; which means the adsorption by clay minerals is occurred. REE concentration is higher at the point $13 \mathrm{~m}$ depth in places like ST14 in particular, the presence of the accumulation zone of REE by ion adsorption suggests. 
There is a tendency which is rich in HREE in ST15, but this may be due to the fact that the LREE is leached earlier by environmental factors and ligands progress of weathering, $\mathrm{pH}$, such as ionic strength. In the basalt sample, tailing is the rich in HREE. It is considered that the clay minerals have been removed from the ore by water washing process.The difference of REE concentration is likely due to the size of the particles.

\section{Hành vi địa hóa của nguyên tố hiếm kết hợp với quá trình Laterite hóa tại tỉnh Đaklak, Nam Việt Nam}

- K. Okamura

- K. Watanabe

- K. Yonezu

- Đặng Thương Huyền

- Đỗ Công Dụ

- Trần Anh Tú

Đại học Kyushu, Nhật Bản- okamura-koki@kyushu-u.ac.jp

\section{TÓM TÁT:}

Nhu cầu của nguyên tố hiếm (REE) ngày càng cao phục vụ cho các ngành công nghiệp hiện đại. Sự phong phú của REE giàu hơn so với các kim loại quý như vàng hay bạc. Tuy nhiên, nguồn cung cấp chủ yếu tập trung ở Trung Quốc. Thị phần của các sản phẩm của REE là cao nhất trong năm 2009 (trên 90\%) và được coi như chiến lược quốc gia. Ngành công nghiệp khai thác mỏ ở Việt Nam được phát triển chủ yếu ở phần phía bắc. Khoáng sản tụ kim loại chính phân bố chủ yếu xung quanh Hà Nội, và khoáng sản REE (Đồng Pao) cũng được thăm dò ở tỉnh Lai Châu. Mặt khác, vài mỏ bauxite ở miền nam Việt $\mathrm{Nam}$ và thăm dò REE không thực hiện đủ. Vì vậy, việc nghiên cứu về REE ở miền Nam Việt Nam rất có ý nghĩa. Mẫu được lấy từ chủ yếu là bazan và đá granit. Kiểu REE, thường phong phu trong chondrite, trong đá basalt và laterite thi giảm đều.
Hàm lượng của REE thấp (50-180ppm). REE trong đá magnetite và laterite không có $\mathrm{Eu}$ và $\mathrm{Ce}$ bất thường. Mặt khác, sáng đá màu và laterites có dị thường âm Eu. Khoáng sét đã được quan sát bằng cách phân tích XRD. Kết quả của REE và chiết xuất liên tục chỉ ra rằng các dạng HREE chịu thay đổi và hấp thụ bởi sét và $L R E E$ được thoát ra ngoài. Trong mẫu quặng đuôi tại vị trí Stop 16 chỉ ra rằng nồng độ của HREE cao hơn khoảng 3 lần đến 5 lần so với trước khi tuyển rửa. Dị thường $E u$ bi ảnh hưởng bởi môi trường có tính khử trong quá trình nguội lạnh magma, và đồng thời xem xét dị thường Ce xảy dưới sụ̣ thay đổi dạng tồn tại của $\mathrm{Ce}\left(\mathrm{Ce}^{3+}\right.$ để $\left.\mathrm{Ce} 4+\right)$. $\mathrm{CeO}_{2}$ là không hòa tan với nước trong đất. Từ phân tích XRD, nguyên nhân của nồng độ HREE trong xử lý nước do các các khoáng chất sét.

Từ khóa: Việt Nam, Địa chất, REE, phong hóa, laterite.

\section{Trang 74}




\section{TÀI LIỆU THAM KHẢO}

[1]. Tapponnier P., Peltzer G. and Armijo R. (1986), "On the mechanism of the collision between India and Asia”. In: Collision Tectonics Coward, M.P. and Ries A.C. eds.: Geological Society Special Publications, London 19, pp. 115-157.

[2]. Leloup P.H. and Kienast J.R. (1983), "High temperature metamorphism in a major strike slip shear zone", Earth and Planetary Science Letters, 118, 213-234.

[3]. Tri T.V. ed. (1977), "Geology of Vietnam: the northern part", Science Publisher, Hanoi, pp.354.

[4]. Ngan P.K., Huoc L.H. and Long P.D. (1986), "Lower Paleozoic stratigraphy in Indochina". In: Geology of Kampuchea, Laos and Vietnam, Science Publisher, Hanoi, 30, pp.46.

[5]. Thu T.V. and Tien P.H. (1986), "Cretaceous red continental sediments in Indochina peninsula". In: Geology of Kampuchea, Laos and Vietnam, Science Publisher, Hanoi, pp.81-86.

[6]. Tran D.L. and Nguyen X.B. (1986), Geological Map of Vietnam 1:1,500,000
[7]. Dzanh T. (1986), "Review of the Paleogene and Neogene stratigraphy in Vietnam, Laos, Kampuchea", In: Geology of Kampuchea, Laos and Vietnam, Science Publisher, Hanoi, pp.86-93.

[8]. Miller W.P., Martens D.C. and Zelazny L.W.(1986): Effect of sequential extraction of trace metals from soils. SOIL SCI. SOC.AM.J., Vol 50.

[9]. Kenzo S. (2012), "Adsorption of REE in Weathered Granite and Its Importance for Resources", Journal of the Clay Science Society of Japan, Vol.50, No.3, 99128-134, 2012.

[10]. Yoshio T. (2002), "Oxidation State of Cerium in Rocks and Its Geochemical Implications", The Japanese Society of Synchrotron Radiation Research, Vol.15, No.2, pp.86-95, 2002.

[11].Hiroyasu M. and Shunzo I. (2006), "REE geochemistry of weathered Miocene granitoids in the Ashizuri-misaki area, SW Japan: possibility as REE resources", Geochemical Journal, Vol.40, pp.147-165, 2006 